Article

\title{
The Division of the Roman Catholic Church in Mainland China: History and Challenges
}

\author{
Rachel Xiaohong Zhu \\ School of Philosophy, Fudan University, Shanghai 200433, China; xiaohongzhu@fudan.edu.cn \\ Academic Editor: Mark G. Toulouse \\ Received: 19 October 2016; Accepted: 6 March 2017; Published: 14 March 2017
}

\begin{abstract}
The paper offers a historical perspective on the division within the Roman Catholic Church in mainland China, focusing on the appointment of bishops, the constitution of ecclesial provinces and dioceses, and the problematic establishment of the national church organization. The current state of Sino-Vatican relations both reflects this division and serves as a precondition to positive steps that might heal the division. An initial concordat on the appointment of bishops may serve as a primary step, but a larger challenge confronts the Chinese church in its movement toward reconciliation.
\end{abstract}

Keywords: Catholic Church in mainland China; church division; Sino-Vatican relations

\section{Introduction}

The Catholic community in mainland China comprises less than $1 \%$ of the nation's population of 1.4 billion. This identified membership exists in more than just one church. Western media and other outside observers are aware of two organizational networks-what many define as the "official church" seen as functioning without true religious freedom, and the "underground" church which some view as the organization most faithful to the orthodox Catholic beliefs and practices. The official church is governed by the joint conference of the government-sponsored Chinese Catholic Patriotic Association (CCPA) and the Bishops' Conference of the Catholic Church in China (BCCCC) abiding by the rules of the principles of independence and autonomy, self-management, and democratic administration of the Church. ${ }^{1}$ The underground church is not registered with the BCCCC and the CCPA, and so it cannot legally carry out its ministry. The faithful within the underground churches are therefore not included in the official church statistics. Their presence is a challenge for the government religious administration. Yet Chinese Catholics form an authentic church. Whether they function publicly or as members of underground communities, they all use the same Bible and missal texts. Both communities pray for the Holy Father when they celebrate the liturgy, the same as the universal church does, with no difference in orthopraxis and orthodoxy (当行当信 dang xing dang xin). Although they hold a different attitude about the authority of the CCPA, most of the faithful do not concern themselves with this political issue. Rather they participate in their church in the way in which they feel most at home and at a convenient location.

Generally speaking, the interrelation between church and state brings about different reflections and expectations. Sinicization has been a complex issue and a compelling mission for Chinese Christians and scholars since President Xi Jinping took over as the leader of China. Some scholars accept that Chinese Christianity or Chinese Catholicism is an outcome of this process of Sinicization. ${ }^{2}$ However, "Chinese Catholicism" represents an unacceptable terminology for many Catholics in

良性循环 liang xin xun huan, which means a good process of operation for the church system ([1], p. 202).

Mr. Zuoan Wang, the chief of the National Bureau of Religious Affairs once put forward that Christian adaption to the Chinese society means the transformation of Christianity in China to Chinese Christianity [2]. 
China, as the Roman Catholic Church is universal and this terminology seems to overemphasize the particularity of the local Church and implies a spirit of schism. ${ }^{3}$ Moreover, the church has been involved in "inculturation" for decades and this carries a somewhat similar agenda which is less political and does not involve the instrumentalization of the church as often happens with Sinicization.

Unfortunately these different viewpoints between church and state have created and maintained division within the church in China, although it has not been serious enough to create schism within the church. ${ }^{4}$ This situation leads us to discuss the reality of the division in the Church in China, the historical factors impeding the reconciliation of churches, and the relationship between China and the Vatican. Much has been written on these topics, but not often by local Catholic scholars in Mainland China. This present article addresses the problematic issues also referred to in the Letter of the Holy Father, Pope Benedict XVI to the Catholic Church in China on 27 May 2007 [5] and other documents [6], and traces the continuing process of negotiation between Beijing and the Vatican. The goal is to analyze what principles were employed in the efforts to solve these long-standing problems.

According to Cardinal Fernando Filoni, the Prefect of the Congregation for the Evangelization of Peoples, the Pope is aware of the division within the Church in China, but does not consider it as a serious concern [7]. Talks between the Vatican and China started in 2014 and have reached a fourth round of meetings. Details of the content of the discussion are not yet publicly available but it is clear that there is a sincere wish on both sides to improve the relationship between the Vatican and China [8].

Although the Vatican has been experiencing many changes since 2007, the letter issued by Pope Benedict XVI on May 2007 facilitates an understanding of the Vatican's attitude regarding the complex circumstances surrounding the Church in Mainland China [9]. The letter responds to numerous concrete questions raised in recent years, such as the tensions and divisions within the Church and with Chinese civil society, the function of national organizations, the appointment of bishops and the exercise of their pastoral ministry, the celebration of the Sacraments, and the recognition and circumscription of ecclesial provinces and dioceses.

If not handled carefully, those closely-related questions can easily divide the church community. Thus it is important to understand the historical background regarding the questions of the appointments of bishops and the circumscription of ecclesial provinces and dioceses, and to clarify the function of the national organizations that are involved. ${ }^{5}$

\section{The Appointment of Bishops and the "Vietnam Model"}

An Italian missionary priest, Giovanni da Montecorvino (1246-1328), first introduced Catholicism into China in 1224 during the Yuan Dynasty (1206-1368), but the Church was expelled from China completely at the beginning of the Ming Dynasty (1368-1644). Jesuit missionaries worked diligently to reintroduce Catholicism to Chinese at the end of the Ming Dynasty. Gregory Lou Wenzao (1616-1691), a Dominican priest, was appointed as the first native Chinese bishop in 1674 and was consecrated in 1685. At the beginning of the Qing Dynasty (1638-1912), authorities again banned Roman Catholicism. This time the ban lasted until the 19th century when the Qing Imperial government signed the "unequal" treaties with the Western countries. Under the protection of "unequal" treaties, missionaries were allowed to come into China once again. A foreign bishop was in charge of the missionary work in China at that time. However, the Apostolic delegate, Celso Constantini (1876-1958), possessed a

3 At the Convention of the 400th Anniversary of the Catholic Shanghai Diocese, 2008, Fr. SavioTai-Fai Hon, who now is the Archbishop and Secretary of Congregation of Evangelization of People, was strongly against the usage of the terms China Catholic Church and Shanghai Catholic Church, and recommended Roman Catholic Church in China or Roman Catholic Church Shanghai Diocese instead. He reclaimed the theological difference between these two sets of terms again during the Conference that memorialized Matteo Ricci in Macerata on May 2011.

4 The Holy See never made any official pronouncement on the official community as schismatic, as Pope John XXIII had been informed of the special and complex situation in China ([3]; [4], p. 12).

5 The sacrament issues are paramount, but not mentioned separately in this paper, as they are inseparable from the other issues. 
different vision about how missionary work should proceed in China. Under his oversight, six native Chinese bishops were ordained at St. Peter's Basilica in 1926. In the wake of this event, more native Chinese bishops were named, thus establishing the foundation for indigenization of Catholicism in China.

Beginning in 1949, authorities in China began to expel foreign clergy. To fill the vacancies, the church appointed 18 native bishops between 1949 and 1955 ([10], p. 28). However, the persecution of the Church continued. By 1958, there were approximately 20 bishops and assistant bishops left in China. ${ }^{6}$ The first two illicit ordinations of bishops, without the approval of the Holy See on 13 April 1958, started the self-electing and self-ordaining process, followed by more than forty episcopal ordinations by $1962 .{ }^{7}$ Since 1958, almost 190 bishops have been consecrated in China by the Chinese Church without approval from the Vatican [15]. Consequently, no Vatican approval existed for the creation of the Bishops' Conference of the Catholic Church in China, established in 1982. Cardinal Tarcisio Bertone, Secretary of State for the Vatican, issued a letter to Chinese bishops and clergy on April 22, 2008, reaching out to most of the 90 bishops in China appointed without the approval of the Vatican, and declaring a pardon by the Holy See [16].

"Self-election" and "self-ordination" is the literal translation of the phrase 自选自圣 (zi xuan zi sheng). ${ }^{8}$ This terminology has been used officially in the Catholic Church in China, that is, bishops are selected by China's authorities and ordained by China's bishops independent of the Holy See. Since the rituals of the episcopal consecration were carried out properly and validly, these bishops are truly bishops. Theologically, these consecrations were "valid" ([13], p. 38). However, because their appointment and consecration took place without pontifical mandate, Church authorities have tended to interpret the Chinese actions in these cases as a rejection of, or at least as an offense against, the primacy these bishops were seen to offend or reject the primary of the papacy. According to the Vatican II decree, "the right of nominating and appointing bishops belongs properly, peculiarly, and per se exclusively to the competent ecclesiastical authority" [17], and the Code of Canon Law, "for the future, no rights or privileges of election, appointment or designation of Bishops are conceded to civil authorities" (CC 377). Thus, juridically or canonically, these consecrations were "illicit" [18,19].

At the pastoral level, for many of the faithful in China, these self-selected and self-ordained bishops have damaged the Church's discipline and unity. Moreover, some consider it dangerous to attend a mass or receive sacraments from a bishop who is valid but illicit, as many local Catholics believe that a bishop's right to govern comes both from the Sacrament of Holy Orders and from the Pope's delegation. In 1958, Pope Pius XII issued the following declaration: "an excommunication reserved specialissimo modo to the Apostolic See has been established which is automatically incurred by the consecrator and by anyone who has received consecration irresponsibly conferred."[20] Although the Roman Pontiff did not declare that any individual had incurred the excommunication ([18], p. 5), many among the Chinese faithful have decided that these bishops are acting without legitimate ecclesiastical authority. ${ }^{9}$

In church praxis, China has unilaterally adopted the distinct system of self-electing and self-ordaining bishops. Scholars note that the Church initiated the Pope's right to appoint bishops only about a hundred years ago and the system of appointment continues under review. In China the act of self-selecting and self-ordaining bishops not only satisfied the need for the church's evangelization, but also simultaneously met the requirements of both Chinese national sovereignty and religious freedom.

6120 out of 145 dioceses (or prefectures apostolic) had no bishops (or prefect apostolic). See On the 40th Anniversary of the Self-election and Self-ordination of Bishops [11,12].

7 The number of ordinations from 1958-1962 varies from forty-two or forty five to forty-eight ([13], p. xiv; [14], p. 38; [4], p. 83). I think forty-two is the exact number as it was confirmed by both Cardinal John Tong and Liu Bainian on different occasions.

8 There is another way to understand how to choose and ordain clergy, which is not used commonly to refer to the ordination of the native priest and bishop with the permission of the Holy See. Xueyan Fan, "Thirteen Points" ([13], p. 142).

9 However, three bishops have received the penalty of excommunication (ferendae sententiae) from June 2011 to July 2012, i.e., Shiyin Lei (雷世银), Bingzhang Huang (黄炳章), and Fusheng Yue (岳福生). 
Thus this distinct system is not only in line with the Church's doctrine, the Church's tradition, and Chinese law, but it also "saved" the Church in China. Lack of clergy is currently a serious problem in China. Among the ninety-seven dioceses in China, more than forty have no resident bishops and fourteen dioceses have bishops who are over eighty years old and currently do not have their own coadjutor bishops [15]. For the Chinese government, they would continue to follow the principle of self-selecting and self-ordaining the bishops until they reach an agreement on the appointment of bishops with the Vatican.

The selection process is intended to identify a person suitable to be in charge of the local church, and the procedure of the election is instrumental. So "unless is has been lawfully prescribed" (CC377), Canon law still holds open the possibility of other procedures.

Some years ago, the media started to bring the "Vietnam Model" to people's attention. Vietnam, a communist country like China, faced difficulties between its Catholic Church and its national sovereignty. When Cardinal Sepe was Prefect of the Congregation for the Evangelization of Peoples, Vietnam and the Vatican reached an agreement that changed their relationship. According to Phoenix Television, there are four steps in the "Vietnam Model": (1) Vietnam selects a number of candidates to become bishops; (2) the Vatican selects one of these candidates to be ordained as a bishop; (3) the Vietnam government reconfirms the Vatican's choice; (4) the Pope appoints the Vietnam bishop. Recent research has discovered that the Holy See has never officially confirmed the "Vietnam Model". On 12 March 2015, Phoenix Television claimed that Father Lombardi, the former spokesperson for the Vatican, suggested during an exclusive television interview that China should adopt the "Vietnam Model" for the appointment of bishops [21]. Some hold that Cardinal Filoni referred to the "Vietnam Model" in his letter to the public in 2012 [22]. However, when carefully analyzed, the statement refers instead to the conditions and possibilities of the communications between the Vatican and Beijing, not to the appointment of bishops. Initiated in this Phoenix Television discussion, talk of the "Vietnam Model" has never been confirmed by either the Vatican or the Chinese government [23]. Perhaps the use of the "Vietnam Model" to solve the problem of appointing bishops in China-a cause of major conflict between the Vatican and Beijing-is simply a rumor. Or perhaps it comes from a general wish for a better relationship between the Vatican and Beijing. The relationship could improve now because both sides respect each other's differences and desire a better relationship defined by mutual flourishing. Based on the goodwill of both parties the communication channel seems to remain open, and it is clear that constructive dialogue is essential if this problem, that is difficult for both the Vatican and China, is to be solved.

\section{Different Constitution of Ecclesial Provinces and Dioceses}

The hierarchical system is a distinctive feature of the Catholic Church. It is seen as representing "the source of Holiness" or "Holy Order". Hierarchy in the Catholic Church is displayed in the roles of bishops, priests, and deacons. Authority rests chiefly with the bishops, while priests and deacons share in the office of the bishop. Overall authority rests with the Pope and the bishops' conferences. The Pope, as the bishop of Rome and successor of Peter, is the top authority in the Catholic Church. So the problem in China lies not only with its appointment of bishops, but also with the authority of the Holy See over the church in China.

It was Giovanni da Montecorvino, a Franciscan priest, who set up the Hierarchy of the Chinese Catholic Church and established the Cambaluc (汗八里 han ba li) Diocese in the Mongol Yuan Dynasty. Many missionary societies, such as the Jesuits, Franciscans, Dominicans, and Augustinians, joined the Chinese mission at the end of the 16th century. In a controversy with Portugal's Patronatus missionum, the Holy See not only set up three dioceses, located in Beijing, Nanjing, and Macau, but also established nine apostolic vicariates. Since then, China's Catholic Church has had two governing systems—vicariate and diocese—existing side by side.

The Holy Father Pius XI issued a pastoral letter in 1922 requesting the establishment of a Pontifical office in China. In 1924, the first National Bishops' Conference was held in Shanghai, during which 137 
mission areas were set out. Among them, 99 became apostolic vicariates and the rest were identified as apostolic prefectures. In April 1946, the Holy See officially set up a hierarchy in China. China was divided into 20 ecclesiastical provinces, 20 archdioceses, and 117 dioceses. In every ecclesiastical province, the church appointed an archbishop who was put in charge of a specific diocese. By 1949, there were 21 archdioceses and 137 dioceses. In the new regimes, dioceses were once again divided by the Chinese Church according to administrative areas; some dioceses were changed, some dioceses were combined, and some dioceses were abolished [24]. There are now ninety-seven dioceses in China. None of these changes are recorded in the Vatican records which means that appointing bishops to govern dioceses is anything but smooth. Recent examples in Harbin and Wuhan illustrate the difficulty encountered during the appointment of bishops.

The first apostolic delegate, Celso Costantini, came to China in 1922. Antonio Riberi (1967-1987) was the first apostolic delegate to arrive in China after China and the Vatican established an official diplomatic relationship in 1943. Riberi was deported from China to Taiwan in 1951. At that point the Church in China entered a very difficult era. After the Second Vatican Council, Paul VI showed goodwill to China. For example, a New Year message was sent to Chairman Mao Zedong in 1966 and good wishes were expressed after Bishop James E. Walsh was released in 1970. However, Beijing did not officially respond to any of these gestures ([25], pp. 275-305).

Pope John Paul II showed goodwill to Beijing in different ways but this cordial period ended when he unilaterally appointed Dominic Deng Yiming as archbishop of Guangdong. In 1999, Pope John Paul II indicated to the Chinese leader that his relationship with Catholics in China is spiritual and this kind of spiritual connection would not weaken China's independence and sovereignty ([1], pp. 189-90). During Benedict XVI's papacy, representatives of China and the Vatican met for discussion. The relationship reached a peak when the China Philharmonic Orchestra performed in the Vatican for the Pope, before the Beijing Olympics in 2008. However, for unknown reasons this period of dialogue came to an end and the relationship hit its lowest point in 2011. Dialogue resumed in 2014 under some difficulties. Each side intensely fought for the right to appoint bishops for the church in China and the problem of the division of ecclesiastical provinces and dioceses, as far as we know, has never been discussed.

Through its hierarchical system, the Roman Catholic Church exercises some authority over its local churches. Most countries do not think this system interferes with their national sovereignty but this is not so for the Chinese government. China has insisted that the acts of managing the Church independently, of self-electing and self-ordaining their bishops, are founded in the Chinese Constitution, which all religions have to follow ([1], p. 190).

Although it has seemed that there is no room to negotiate, many hope that agreement will be reached. Fr. Lazzaroto, an expert of the Chinese Church, states that the Chinese Government has a strong desire to solve both the problem of the appointment of bishops and the division of dioceses, even without an established diplomatic relationship, because they wanted a "harmonious society" ([4], p. 81).

\section{The Chinese Catholic Patriotic Association}

After the People's Republic of China took control of Mainland China, the new Chinese government initiated a series of controversial actions, e.g., confiscating church-funded facilities and schools, deporting missionaries, stopping the relationship with the West, and denying registration of the Legion of Mary ([26], pp. 37-56, 98-102). Between 1951 and 1955, the Chinese authorities deported around 8000 foreign missionaries and many native clergy left China by their own volition ([27], pp. 61-72). Catholic Reform committees were set up to govern the parishes, encouraged by the Religious Affairs Bureau in 1951. The 'patriotic' theme was introduced into the movement in 1954, and Shanghai Bishop Ignatius Gong Pinmei and large numbers of religious and lay Catholics were arrested in September 1955. In mid-June 1957, the Chinese Catholic Patriotic Association (CCPA) was established, after over a month of discussion and preparation ([13], pp. 7-27). 
The founding of the CCPA started a new chapter for the Catholic Church in China. The constitution of the CCPA clearly states that the Chinese Catholic Church must be independent and self-managed, which meant that it was to be completely cut off from the Vatican, both politically and financially, and later religiously. Already in the 1950s, these changes foreshadowed the internal divisions of the Chinese Church. In 1962, during the Second Conference of the Chinese Catholic Church, the CCPA declared that the Chinese Church would "not be controlled by the Holy See in Rome" and would "be fully independent and self-managed." At that time, the Chinese Church ordained an additional seven bishops, bringing the number of bishops functioning by the beginning of the Cultural Revolution to fifty-two ([4], p. 69). Between 1979 and 1996, the church consecrated more than seventy-six bishops without Vatican approval; of these, Bishop Joseph Zong Huaide 宗怀德 (1917-1997) ordained more than forty [28].

After the Cultural Revolution, religious organizations, including the CCPA, began to function once again. The year 1980 witnessed the founding of the Bishops' Conference of the Catholic Church in China (BCCCC) and the National Administrative Commission of the Chinese Catholic Church (NACCCC). The constitutions of the Chinese Catholic Patriotic Association and the Bishops' Conference of the Catholic Church in China were approved while authorities cancelled the constitution for the national level NACCCC in the Fifth National Congress of Catholic Representatives in 1992. In 1996, with a view towards being a "democratic" church, the CCPA and the BCCCC set up a small working group to draft three more sets of regulations: Regulations of the Chinese Catholic Patriotic Association, the Joint Conference regulations for the co-meeting of the Chinese Catholic Patriotic Association and the Bishops' Conference of the Catholic Church in China, and Management Regulations for Chinese Catholic Church Dioceses. ${ }^{10}$ These two constitutions and three sets of regulations formed the basic guidelines regulating the Chinese Catholic church's decision-making process and daily operations [29]. The guidelines establish that the National Congress of Catholic Representatives has the highest authority; the primary mission of the CCPA is to execute the decision of the National Congress under the guidance of the Communist Party and the Government, to ensure that the development of the Church is on the right path, and will be an effective bridge between the faithful and the government. The mission of the BCCCC is to study and to explain the Church's doctrine and dogma of orthopraxis and orthodoxy, to promote evangelization, and to establish pastoral work at the local level.

According to the Constitution of the BCCCC, the bishops' conference is in communion with the Vatican in terms of the Church's doctrine and dogma. However, as a social organization, the bishops' conference must report to the National Congress of Catholic Representatives [20]. In order to ensure the CCPA's authority over church affairs, all important decisions in the Catholic Church need to be approved by both the CCPA and the BCCCC.

\subsection{The CCPA's Dissenters}

After the Cultural Revolution, bishops who did not recognize the CCPA began to aggressively consecrate bishops without government approval. In 1981, Bishop Peter Joseph Xueyan Fan 范学淹 (1907-1992) of the Baoding diocese, ordained a young man with no proper theological training, but who served the church zealously as a priest; he consecrated three bishops without Vatican approval. In the second case, Bishop Fan asked for an exemption from the Holy See. ${ }^{11}$ Pope John Paul II not only granted him the exemption but also gave Bishop Fan his blessing and the authority to make decisions

10 These three sets of regulations released in 2003, between the 6th National Congress of Catholic Representative in 1998 and the 7th National Congress of Catholic Representative in 2004. The first two sets of regulations were adapted and voted on in the 8th National Congress in 2010.

11 Actually, there was a special privilege released to Chinese bishops in 1978 from the Congregation of the Evangelization of People, which allows the bishop to ordain the priest who might not have enough training, but not to ordain the bishop. The document is the Sacra Congregatio Pro Gentium Evangelizatione Seu De Propaganda Fide Facultates Et Privilegia Sacerdotibus Fidelibusque in Territorio Sinarum Degentibus Concessa His Perdurantibus Circumstantiis, the archive number is Prot. N. 3242/78 [30]. 
on church affairs without first receiving the Vatican approval ([30], pp. 30-31). With the Pope's support, Bishop Fan and the bishops whom he consecrated ordained more than eighty bishops. Some of these men later joined the open Church, but sixty three of them had not done so by 1993. Bishop Fan paid with his life for what he had done, but the underground Church in Hebei province expanded greatly. Under the guidance of underground bishops, Hebei province now has the largest Catholic population in China.

Nine bishops in China were granted the same privilege as Bishop Fan, but only four of them used it officially ([30], pp. 32-33). Priests and believers were greatly confused by the different approaches of the underground and approved communities. When Bishop Fan was freed from prison for the third time, he released the so-called "Thirteen Points" ([13], pp. 142-45), which responded negatively to the CCPA and later provided guidance for the underground church in China. ${ }^{12}$

What distinguishes the underground church from the open church is the recognition of the CCPA's idea of an "independent and self-managed Church" and the act of self-electing and self-ordaining bishops. The "Thirteen Points" declares that the CCPA is trying to break away from the Vatican's influence and separate the Chinese Church from the Apostolic Church. The act of self-electing and self-ordaining bishops definitely places the Chinese Church out of communion with the Pope. For this reason, many in China believe that the faithful should avoid receiving the sacraments from the priests who join the CCPA.

In May 1988, the Congregation for the Evangelization of Peoples issued an "Eight-point Directive" document ([10], pp. 172-76; [31]) within which the Vatican not only confirmed the statements that had been made in the "Thirteen Points " document regarding the CCPA, but also granted "full and legitimate exercise of Episcopal jurisdiction" to underground bishops [32]. This document also clearly states that the CCPA "assumes a more political than religious role" (Eight-point Directive no. 2), is not a religious organization in full communion with the universal church, and therefore, is not qualified to direct any ordination of bishops and religious activities. Under the circumstances, the underground bishops gathered for a meeting in the Sanyuan diocese in Shanxi, and founded the Bishops' Conference in Mainland China on 20 November 1989. They elected Bishop Fan Xueyan as the first leader of the Bishops' Conference ([27], pp. 143-45).

Because of strong intervention by the government, the "faithful" Church (the underground Church) cannot expand as fast as the Chinese Patriotic Church. After the millennium, many bishops who had been self-selected and self-ordained were pardoned by the Pope, including the Shanghai bishop, Aloysius Luxian Jin. As an important member of the CCPA, Bishop Jin insisted on the communion of the Chinese church and the universal church, and his efforts and contributions are commendable. In 2007, the Pope Benedict XVI withdrew the privileges that had previously been given to some of these Chinese bishops. This act encouraged the divided churches to be in communion by faith ([30], p. 37).

\subsection{The Vatican and the CCPA}

According to Canon Law, the Holy See would have difficulty approving the CCPA, which is a political organization through which the free exercise of the bishops' responsibility itself is restricted and the government effectively controls the Church. As the Pope indicated in his pastoral letter, the CCPA has five characteristics: (1) it was established by the government; (2) it is an organization which has no connection with the Vatican; (3) it is an organization which claims authority above that of the

12 The Thirteen Points was actually a reply to 13 questions raised by a Catholic in the form of question-and-answer. 12 out of 13 points directly addressed how one should understand the CCPA, sacraments provided by the priests in the CCPA, and other details related to the CCPA. For example, the first question: Because the CCPA claims the principle of independence and self-management, getting rid of the interference of external forces, is it still in the same one holy Catholic church? (Question. 1) The answer is no. The third question: Are the sacraments performed by these "reformed priests" in CCPA effective? Will these priests have the right of absolution? Can the faithful attend the mass presided by these priests? These answers are also no. 
bishops; (4) it has taken leadership of the church community; and (5) it does not comply with church doctrine. The question remains: if those characteristics changed, especially the third and fourth, is the CCPA still needed?

Wang Meixiu, an expert on the Catholic Church in China, has observed: (1) When authorities founded the CCPA, its focus was to be independent of the influence of imperialist countries, politically and economically. Its original intention did not include a denial of the religious/spiritual relationship between the Chinese Church and the Vatican. Therefore, people should not only understand the CCPA's unique position in history but also recognize and accept its existence ([33], pp. 115-17) Many religious people agree that since the CCPA is not a religious organization, bishops did not violate the Church's doctrine when they obeyed the requests of a political organization. Shanghai Bishop Jin observed, "Our church is the Catholic Church. We did not found a new Church ... the CCPA is not part of the church but a political community ... the CCPA is an important organization that has offered great help to the Catholic Church in China." ([34], esp. p. 4); (2) The existing model of the CCPA and the BCCCC in the Chinese Church needs to be adjusted. The BCCCC should take more responsibility and the role of the CCPA should be changed: "According to the international structure of the Catholic Church, the Chinese church needs to make some adjustment. A structural adjustment of the Chinese church can be effected only when all bishops join the BCCCC and take over the responsibility to lead the Chinese church ... After changing its role, no doubt the CCPA would have its new function ... " [35] In reality, at this time asking to abolish the CCPA is not possible. Bishops cannot avoid cooperating with the CCPA, but they also need to defend communion with the universal church. If the constitution of the CCPA and its regulations were not adjusted to meet the needs of the current situation, the bishops would continue to be pressured from both sides. Seeing the reality of the problem, Rev. Angelo S. Lazzarotto has offered this recommendation:

It has been suggested to the Chinese authorities, as a conciliatory gesture, to empower the leadership of the Chinese Bishops Conference to study and approve a number of amendments to their constitution, in order to make it fully consistent with universal Catholic doctrine and praxis. The Patriotic Association should carry out a similar work on their Statutes, cancelling, for example, the rule that requires all important decisions of the Bishops Conference to be approved by them too. Such revisions would open the doors of membership of the Bishops Conference to all Chinese bishops, and would facilitate its recognition by the Holy See. ([4], pp. 133-34)

Since the government agrees that the CCPA is not a religious organization and also accepts that-according to canonical understanding-the BCCCC is in communion with the Pope, this organization should be able to negotiate with the underground church and invite those bishops who were approved by the Pope but not the government to join the BCCCC. Moreover, if the constitutions of the BCCCC and the CCPA are going to be amended, the acceptance of the Patriotic Association would become less problematic for the conscience of those faithful in Catholicism ${ }^{13}$. All these problems relating to the CCPA and its dissenters must certainly be discussed in working groups between the Vatican and China.

\section{The Sino-Vatican Diplomatic Relationship}

Professor Zhuo Xinping, when talking about the Chinese state-church relationship, mentioned a new model-"the government dominant, the church obedient". In his understanding, this relationship differs from forms of secularism or theocracy in Western countries [37]. It implies that government should be in the leading position when facing religious problems. Some critics comment that the

13 Fr. Jeroom Heyndrickx once described the problematic situation as "walk that thin line between the Communist government and his faith" [36]. 
lack of freedom in a state where Atheism and Marxism are the ruling ideologies is the fundamental problem at play in all the issues mentioned above [38]. Nevertheless, the external relationship between the Vatican and China is a "precondition" for any healing of wounds and divisions in the Chinese church [18].

Strictly speaking, the Vatican is not a political country but a religious entity ([39], p. 28). Even though China has no diplomatic relationship with the Vatican, the religious connection is always there $^{14}$. Prof. Wang Meixiu has observed that many Chinese believe that the Sino-Vatican relationship is essentially a diplomatic relationship, and this diplomatic relationship must be established before any other ties can be established [40]. Some church people also expressed similar viewpoints. For instance, Bishop Jin Peixian has commented that all the problems and obstacles could be attributed to the conflict between evangelization and local political culture ([41], p. 3). Traced back to the year 1997, the same opinion had been expressed by the State Council in its white paper: "the foremost problem in the Sino-Vatican relationship is the lack of diplomatic relationship. Only after it has been established, all the other religious issues could be solved." [42]

\subsection{The Government's Two Principles on the Sino-Vatican Relationship}

Beijing has only two principles relating to the Sino-Vatican relationship. First, the Vatican has to end its diplomatic relationship with Taiwan, and recognize the People's Republic of China as the only legitimate government of China. Second, the Vatican must not interfere in China's internal affairs, including all issues that might be addressed in the name of religion.

Regarding the first principle, Cardinal Angelo Sodano, the Vatican's former Secretary of State, already explicitly asserted in 1999 that, if China agreed, the Vatican was ready to move its nunciature from Taipei to Beijing overnight ${ }^{15}$. The diplomatic relationship between the Vatican and the government of the Republic of China was established in 1942 and the Vatican is the only European country with which Taiwan maintains a diplomatic relationship today. The Chinese government has repeatedly asked the Vatican to end its diplomatic relationship with Taiwan because of this first principle. From Beijing's perspective, the importance of these two principles is not related to the order in which these diplomatic initiatives are undertaken. Rather, everything depends on the tension between China and Taiwan. For example, when Ma Yingjiu was President of Taiwan, the relationship between Taiwan and Mainland China existed under better conditions. Under the "peaceful reunification of Taiwan" policy, China relaxed the first principle during that time. Howeveer, when Taiwan's ruling party changes, the first principle may become an urgent matter again ([25], p. 387). Since the Vatican is a small state with few economic or other advantages, the Chinese government seldom gives consideration to issues other than those involved in direct Sino-Vatican relations ([44], pp. 11-12).

Regarding the second principle, the interpretation of China's so-called internal affairs differs to a fair degree between China and the Vatican. Let us go back to the problems we mentioned before and the bishop-appointment policy over the last sixty years. The government considers this responsibility as part of its sovereign right. However, the appointment of bishops by the Pope is a principle of the Catholic Church. If this is not respected, the Catholic Church would no longer be the Catholic Church. Even when the governments of certain countries are involved in the initial scrutiny of candidates, the bishops are ordained only after the Pope gives his approval.

14 The first Apostolic Nuncio Antonio Riberi came to China in June 1946. However, Msgr. Riberi was expelled from his home in Nanjing on 4 September 1951, and forced to flee to Taiwan the year after. After the UN recognized the People's Republic of China as the "sole legitimate representative of China" at the United Nations, the Holy See recalled its apostolic nuncio from the Taipei mission in 1971, while it kept the status of embassy up to now. According to the One-China policy, the diplomatic relationship has always been there.

15 However, Taiwan has been one of the bridge churches, and would not be a factor that is easily neglected [43]. 
Behind the principle of "no interference in Chinese internal affairs" is a strong obsession for nationalism. Many in the government believe that missionaries are deeply involved in Western countries' colonial plan for China. Wherever domestic, political, economic, and ideological situations get worse, this negative voice gets much louder. Nationalism is also expressed by another kind of statement. At the beginning of New China, the CCPA sent the Holy See a report on the election of bishops. As with most Western countries at the time, the Vatican did not recognize New China as the authentic government of China and refused the request. So, the Chinese started to take care of their own religious affairs, and have established independent financing and ways of democratic support for religious affairs. The Chinese believe that they have been doing well and do not need any interference from the outside [45]. However, it is a worthy question to ponder, regarding the matter of the election of bishops: does the Vatican interfere with the government's internal affairs, or does the government interfere with the Church's internal affairs?

\subsection{Religious Freedom and World Peace}

To many who are religious, the main purpose of a Sino-Vatican relationship is not to establish diplomatic ties but to grant religious freedom for six million of the faithful Catholics [46]. In the Chinese Constitution, article 36 sets the terms for religious freedom. The Government emphasizes the last part: "Religious bodies and religious affairs are not subject to any foreign domination", they care about the sovereignty of the country, and claim that religious freedom and self-managed religion can co-exist. Westerners, meanwhile, quote the first part which focuses on religious freedom: "No state organ, public organization or individual may compel citizens to believe in, or not to believe in, any religion; nor may they discriminate against citizens who believe in, or do not believe in, any religion". Cardinal Filoni once said: "Does not the Church have the legitimate power to defend the faithful in China, when their religious freedom has been restrained or even taken away? Does not the Holy See have the responsibility to defend them?" [7]

However, Pope Francis and the Secretary of State for the Vatican, Card. Pietro Parolin, are much more practical with regards to the Vatican's foreign affairs. They promote the "Ostpolitik" which was affirmed by Pope Paul VI ([25], p. 71). As the ambassador of Christ and for the good of the Church, the Vatican is trying to open up dialogue with communist countries, seeking the possibility of reconciliation and working on world peace together. Historically, China has been the beneficiary of the Vatican's "Ostpolitik". Pope Paul VI actively supported China's efforts to join the United Nations, insisting that world peace would be impossible without China's participation. Pope Francis has expressed the same idea on many occasions, and has been working toward improving the Sino-Vatican relations.

On the other hand, as a country the Vatican is not a member of the United Nations, but it is a Perpetual Observer at the United Nations. The Vatican is unique: this can be seen in its particular authority concerning moral issues, its powerful influence and neutral position on international affairs, its expansive information and personal networks, etc. All those unique qualities help the Vatican to establish multiple relationships with various international organizations, and to play an important mediating role to promote peace on earth. Examples include when Pope Francis helped the United States of America and Cuba to become diplomatic allies, when he met with the leader of the Orthodox Church, and other papal initiatives which have changed international geopolitics. The media call him the strongest "soft global power" in the world [47]. When the Pope encourages Sino-Vatican talks on the world stage, the Chinese government is able to recognize the Vatican's intention for peace.

\subsection{Concordat on Bishop Appointment or Package Arrangement}

When Sino-Vatican talks resumed in 2014, the Chinese media optimistically reported that China and the Vatican had reached an agreement regarding the appointment of bishops which has been discussed four years earlier. There was admission that the main obstacle to the Sino-Vatican relationship was the principle of "single handed administration of the church" or its being "independent and self-managed." [48] After four rounds of talks and the subsequent effort of the working group, there 
was a breakthrough [8]. Cardinal John Tong Hon also carefully affirmed that an agreement on the appointment of bishops, which would be a step forward in diplomatic relations, would help promote the reconciliation of the church in China and within the universal church $[49,50]$.

However, some Catholics showed less optimism toward China-Vatican negotiations and the accord regarding the ordination of bishops [51]. Cardinal Joseph Zen Ze-Kiun even commented that an agreement on the appointment of bishops between the Vatican and China would be to surrender to China [52]. Neither Catholics in underground communities nor those in open communities fully believe a concordat would improve the situation for the church in China. They insist that Sino-Vatican talks do not simply discuss the problem of the appointment of bishops but that they also deal with the division of dioceses, the function of the CCPA, because all these problems are closely related. Simply signing an agreement which addresses the problem of the appointment of bishops would not satisfy all sides. Neither China nor the Vatican want to announce such an accord too quickly; they want to take time to discuss and solve the problems, and as a result are dealt with by working groups [53].

"The Chinese Catholic Clergy Confirmation Method" was passed in 2009 [54] and by the end of 2016 the government would issue certificates to all religious clergy [55]. However, many priests in the underground church do not agree with the principle of "single handedly administering the Church" and also does not recognize the CCPA's function in the church. Neither will they give up the principle which they have insisted on for decades, nor can they apply for certification. If China and the Vatican establish diplomatic relations without solving these problems, it will put those underground clergy in a very awkward situation; they would feel betrayed by the Vatican and might also be persecuted by the government [56].

\section{Conclusions: When Is God's Time?}

On the one hand, new political leaders always bring something different to religious policies. The high-profile National Conference on Religions on 23 April 2016, at which Jinping Xi delivered an address and five other top leaders attended, did not propose specific instructions to the Catholic Church along those conventional lines such as the principles of religious independence and self-administration, or adaption to a socialist society [57]. However, in consideration of the "Cross Demolition" event in Zhejing [58] a few years ago and Rule no. 23 in the "Chinese Communist Party Regulation in United Front Work (on trial)" [59] which states that members of the Communist party should not believe in any religions, the strong attitude of the current government toward the demand that the Catholic Church work for the sinicization of the Catholic Church is visible. It is a typical attitude among officials in religious affairs that China possesses the authority to decide whether or when to build Sino-Vatican relations [60].

On the other hand, establishing Sino-Vatican relations might help solve the problems of division that continue for the Chinese Catholic Church. Yet there is one thing to keep in mind. Even if Sino-Vatican relations improve, the church structure of priests, religious believers, and lay believers would not change, nor would the quality and the capability of the Chinese church in mission work and social work improve automatically. From the appointment of bishops, to the circumscription of ecclesial dioceses, to the CCPA, we might see the kind of mentality Prof. Richard Madsen described as a "hierarchical imagination" ([14], p. 48). The rigid pre-Vatican II understandings of ecclesiology, sacrament, eschatology, etc., which are still widespread, the bitterness inherited from past suffering, as well as a polarized society, make the divisions more serious in recent years.

As long as China and the Vatican remain willing to talk and to work on finding solutions for the problems of the Chinese Church, the discussions may eventually introduce mutual understanding and provide hope for all the people involved. Even though it may take a long time and will have its ups and downs, believers remain hopeful that these many interruptions ([61], p. 42) may yield in time to a satisfying reconciliation between church and state. 
Acknowledgments: Appreciation to James Whitehead and Evelyn Whitehead, Rev. Francis Fang and his friends, Rev. Warren Kinne, Israel Polo, and Cecilia Tao for their generosity of improving my English expressions in this paper.

Conflicts of Interest: The author declares no conflict of interest.

\section{References}

1. Xiaowen Ye (叶小文). The Theoretical Innovation and Practical Exploration to the Chinese Religious Problems (中国破解宗教问题的理论创新和时间探索). Beijing: Party School of the Central Committee, 2014.

2. Zuoan Wang (王作安). “Speech on the 60th Anniversary Conference of the TSPM (王作安局长在中国基督教 三自爱国运动委员会成立60周年纪念会上的讲话).” Available online: http:/ /www.ccctspm.org/sanzishiliao/ 2016/127/16127860.html (accessed on 23 April 2016).

3. “A Turning Point in China-Church Relations: A Commentary." Tripod 15 (2000): 13-18.

4. Angelo S. Lazzarotto. What Future for the Church in China. Hong Kong: Holy Spirit Studies Center, 2013.

5. "Letter of the Holy Father to the Bishops, Priests, Consecrated Persons and Lay Faithful of the Catholic Church in the People's Republic of China." Available online: http://w2.vatican.va/content/benedict-xvi/ en/letters/2007/documents/hf_ben-xvi_let_20070527_china.html (accessed on 23 April 2016).

6. "Explanatory Note Letter of His Holiness Pope Benedict XVI to Chinese Catholics." Available online: http://w2.vatican.va/content/benedict-xvi/en/letters/2007/documents/hf_ben-xvi_let_20070527_ china-note.html (accessed on 23 April 2016).

7. Card. Filoni. "Reflection on the Pope's Letter after Five Years." Asia News. Available online: http:/ / www. chinacath.com/e/pl/?classid=408\&id=18359 (accessed on 10 October 2015).

8. Lim Lisa Jucca, Benjamin Kang, and Greg Torode. "Special Report: After Decades of Mistrust, Pope Pushes for Breakthrough with China." Available online: https:/ / www.yahoo.com/news/special-report-decadesmistrust-pope-pushes-breakthrough-china-131020495.html (accessed on 29 August 2016).

9. Card. Filoni. "Pope's Letter to the Church in China Still Waiting for an Answer." Available online: http:/ / www.asianews.it/news-en/Card-Filoni:-Pope's-Letter-to-the-Church-in-China-still-waiting-foran-answer-26191.html (accessed on 10 October 2015).

10. Anthony S. K. Lam. The Catholic Church in Present-Day China: Through Darkness and Light. Hong kong: Holy Spirit Study Center, 1997.

11. “On the 40th Anniversary of the Self-election and Self-ordination of Bishops." China Religion (中国宗教) 2 (1998): 42-43.

12. Bainian Liu (刘柏年). “Self-election and self-ordination saved the Church in China, which is the Lord's Plan (选圣主教, 挽救了中国教会, 这是上主的安排).” Catholic Church in China (中国天主教) 1 (2009): 11-14.

13. Edmond Tang, and Jean-Paul Wiest, eds. The Catholic Church in Modern China: Perspectives. New York: Orbis Books, 1993.

14. Richard Madsen. China's Catholics: Tragedy and Hope in an Emerging Civil Society. Berkeley and Los Angeles: University of California Press, 1998.

15. Chinese Ethnic and Religion Net (中国民族宗教网). “Insist Promoting Self-Selection and Self-Consecration of Bishop (坚持推进自选自圣主教).” Available online: http://www.mzb.com.cn/html/Home/report/3126841.htm (accessed on 29 August 2016).

16. Bernardo Cervellera. "The Bishop of Beijing, the Vatican and Compromising with the Patriotic Association." Asianews, 3 February 2009.

17. "Decree Concerning the Pastoral Office of Bishops in the Church, Christus Dominus." Available online: http://www.vatican.va/archive/hist_councils/ii_vatican_council/documents/vat-ii_decree_ 19651028_christus-dominus_en.html (accessed on 29 August 2016).

18. Geoffrey King. “The Catholic Church in China: A Canonical Evaluation.” Tripod 69 (1992): 4-30.

19. Stephen Lee. "Response to Geoffrey King's Article." Tripod 69 (1992): 36-38.

20. Pius XII. "Ad Apostolorum Principis Encyclical of Pope Pius XII, on Communism and the Church in China." Available online: http://w2.vatican.va/content/pius-xii/en/encyclicals/documents/hf_p-xii_enc_ 29061958_ad-apostolorum-principis.html (accessed on 29 August 2016). 
21. Jie Cao (曹), and Yuexin Liang (梁悦信). “The Holy See: The Vatican's Bishop Appointments Can Learn from the Vietnam Model (罗马教廷: 中梵就主教任命问题可借鉴“越南模式”).” Available online: http: / /news.ifeng.com/a/20150312/43322060_0.shtml (accessed on 12 October 2015).

22. Guopeng Liu (刘国鹏). “The Development of Chinese Catholicism and the Influence from European Catholicism (2012年中国天主教发展及欧洲天主教的影响).” In Blue Book of Religions: Chinese Religious Report 2013 (中国宗教蓝皮书2013). Edited by Ze Jin and Yonghui Qiu. Beijing: Social Science Documents Press, 2013, pp. 143-79.

23. Xiaolan Zhang (张小兰). “The Vietnamese Model of Bishop Appointment into Rashomon (走进“罗生门”的 越南模式主教任命).” Available online: http://weibo.com/p/1001603844243394318686?from=page_100505_ profile\&wvr=6\&mod=wenzhangmod\&sudaref=passport.weibo.com (accessed on 12 October 2015).

24. Qing Yuan Zhao (赵庆源), ed. The Division of Catholic Diocese in China and the Heads Replacement Chronology (中国天主教教区划分及其首长接替年表). Taiwan: Catholic Window Press, 1980.

25. Beatrice Leung (梁洁芬). Sino-Vatican Relationship from 1976-1994 (中共与梵蒂冈关系1976-1994). Taiwan: Fujen University Press, 1995.

26. James T. Myers. Enemies without Guns: The Catholic Church in China. New York: Paragon House, 1991.

27. Beatrice Leung, and William T. Liu. The Chinese Catholic Church in Conflict: 1949-2001. Boca Raton: Univeral Rublishers, 2004.

28. “The Vatican Neither Recognized the New China Nor Acknowledged the Chinese Bishop (梵蒂冈不承认新 中国宗怀德未获教宗认可).” Available online: http://phtv.ifeng.com/program/xwjrt/detail_2014_01/27/ 33415947_1.shtml (accessed on 27 August 2016).

29. Bainian Liu (刘柏年). “A New Understanding of the Significance of Democratic Management (重新认识民主 办教的意义)." Available online: http://www.mzb.com.cn/html/report/1602245781-1.htm (accessed on 15 October 2015).

30. Anthony S. K. Lam. ; Translated by Aijie Chen. "The Historical Significance of the Secret Bishop Consecration in China, 1981." Tripod 163 (2011): 28-37.

31. "Eight-point Directive (Chinese Version)." Available online: http://wenku.baidu.com/ link?url=MC6cvYFc3tL8Yq868GeIHbcNS5TkqjS2Tszj8qo00GJtscVM5zxFCDFoU89ByzGNAyJQbMjahQQ9o275UCqydGKyHYU9cZO6sp1r9DhHgy (accessed on 3 September 2016).

32. UCAN News. "Card. Josef Tomko on 8 Instruction." 7 December 2007. Available online: http: //www.radiovaticana.va/proxy/cinesegb/notiziari/notiz2007/notiz07-12/not0712-10.htm (accessed on 3 September 2016).

33. Meixiu Wang (王美秀). “The Observation and Comments on the 2010 Catholic church in China (2010年中 国天主教观察和评论).” In Blue Book of Religions: Annual Report on Religions in China. Edited by Ze Jin and Yonghui Qiu. Beijing: Social Sciences Academic Press, 2011, pp. 101-27.

34. Luxian Jin (金鲁贤). “The Opening Address on Shanghai CCPA Symposium.” Catholic Research Material Collection (天主教资料汇编), 1990, 3-11.

35. Meixiu Wang (王美秀). “Sino-Vatican Relations: Only Cooperation could Lead to the Ice-Breaking and Win-Win (中梵关系: 只有双方合作才能打破僵局实现共赢).” Available online: http://blog.sina.com.cn/s/ blog_6720e12c0102vvc6.html (accessed on 3 September 2016).

36. Fr. Jeroom Heyndrickx. "We Gratefully Remember Mgr. Louis Jin Luxian-Bishop of Shanghai." unpublished paper. 2016.

37. Xinping Zhuo. "Religious Studies in Contemporary China: Problems and Approaches." In Blue Book of Religions: Annual Report on Religions in China (2008) (中国宗教蓝皮书2008). Edited by Ze Jin and Yong Hui Qiu. Beijing: Social Sciences Academic Press, 2008, pp. 1-15.

38. Michael C. Mi. "Five Obstacles to Sino-Vatican Reconciliation." Tripod 95 (1996): 5-21.

39. Zhusheng Du (杜筑生). The International Status of the Holy See and Its Relations with China. Taibei: Fujen University Press, 2014.

40. Meixiu Wang. "Sino-Vatican Relations: Status Quo and Analysis." In Blue Book of Religions: Annual Report on Religions in China. Edited by Ze Jin and Yonghui Qiu. Beijing: Social Sciences Academic Press, 2008, pp. 178-91.

41. National Administrative Commission of the Chinese Catholic Church, ed. Love Country and Religions, Promote Harmony: Symposium Collection. Beijing: BCCCC\&CCPA Press, 2007. 
42. The State Council Information office of PRC. "A White Paper on the Freedom of Religious Belief in China. " Available online: http:/ /www.scio.gov.cn/zfbps/ndhf/1997/Document/307974/307974.htm (accessed on 7 September 2016).

43. Beatrice Leung, and Marcus J. J. Wang. "Sino-Vatican Negotiations: Problems in Sovereign Right and National Security." Journal of Contemporary China 99 (2016): 467-82. [CrossRef]

44. Fangzhong Chen, and Guoxiong Jiang. The History of Sino-Vatican Diplomatic Relationship. Taiwan: Commercial Press, 2003.

45. Panpan Wang. “Official Slams Vatican's Criticism.” Available online: http://www.globaltimes.cn/content/ 603644.shtml (accessed on 15 September 2016).

46. Min Hua (华民). “On Sino-Vatican Relationship and its Future.” Tripod 178 (2015): 14-20.

47. Gianni Valente. "China has Become Aware of Pope Francis' 'Soft-Globalpower'." Available online: http:/ / www.lastampa.it/2016/02/27/vaticaninsider/eng/the-vatican/china-has-become-aware-ofpope-francis-softglobalpower-3aLnVym25TTUdwsD93gqRN/pagina.html (accessed on 3 September 2016).

48. GuanChaZhe Net (观察者网). “HK Media: China and Vatican almost Reach the Bishop Appointment Agreement." Available online: http://www.guancha.cn/culture/2014_11_20_301138.shtml (accessed on 12 May 2016).

49. Card. Tong. "Communion of Church in China with the Universal Church." Available online: http://kkp.org. hk/node/12388 (accessed on 4 September 2016).

50. Ucanews. “Cardinal Tong Rebuffs Criticism on China-Vatican negotiations." Available online: http://www. ucanews.com/news/cardinal-tong-rebuffs-criticism-on-china-vatican-negotiations/76776 (accessed on 3 September 2016).

51. Ucanews Reporter. "Little Optimism toward China-Vatican Negotiations." Available online: http: //www.ucanews.com/news/little-optimism-toward-china-vatican-negotiations/76835 (accessed on 8 September 2016).

52. "A Retired Bishop in Hong Kong Has Said Allowing the Chinese Government to Appoint Catholic Bishops Would Mean 'Surrender'." Available online: http:/ / www.cardinalrating.com/cardinal_214_article.htm (accessed on 4 September 2016).

53. Ucanews. "Vatican Pushes for Working Group in Search for China Deal." Available online: http://www. ucanews.com/news/vatican-pushes-for-working-group-in-search-for-china-deal/76024 (accessed on 5 September 2016).

54. “Chinese Catholic Clergies Confirmation Method (中国天主教教职人员认定办法). ” Available online: http:/ / www.sara.gov.cn/zcfg/qgxzjttxgjgzd/6383.htm (accessed on 10 September 2016).

55. Pengpai News (澎看新闻). “Taoist and Catholic Clergy Will Get Their Certificates by the Year of 2016." Available online: http://www.thepaper.cn/www/v3/jsp/newsDetail_forward_1420897 (accessed on 20 May 2016).

56. Jennifer Thompson, and Joseph Zen. “The Hong Kong Cardinal Standing up to Beijing." Financial Times, 8 September 2016.

57. Xinhuanet. "Xi Calls for Improved Religious Work." Available online: http:/ /news.xinhuanet.com/english/ 2016-04/23/c_135306131.htm (accessed on 20 September 2016).

58. Gospel Times (福音时报). “The Disturbance of Cross Demolition in Zhejiang (基督教十大焦点回顾 (二): 浙江十字架风波).” Available online: http://www.gospeltimes.cn/news/33672/2014 (accessed on 20 September 2016).

59. Xinhuanet. "China Publishes Regulation on CPC's United Front Work." Available online: http://news. xinhuanet.com/english/2015-09/23/c_134649610.htm (accessed on 20 September 2016).

60. Quan Yuan (原泉). “There is not much Time for this Rebellion Pope to the Sino-Vatican Relations (中梵关系 正常化，留给“叛逆教皇”的时间不多了).” Available online: http://www.guancha.cn/YuanQuan/2016_06_ 01_362432_2.shtml (accessed on 20 September 2016).

61. Lieven Boeve. God Interrupts History: Theology in a Time of Upheaval. New York: Continuum, 2007.

(C) 2017 by the author. Licensee MDPI, Basel, Switzerland. This article is an open access article distributed under the terms and conditions of the Creative Commons Attribution (CC BY) license (http:/ / creativecommons.org/licenses/by/4.0/). 